\title{
Overcoming dormancy in seeds of Pterodon pubescens (Benth.) Benth. (Leguminosae,
}

\section{Papilionoideae)}

\author{
Superação de dormência em sementes de Pterodon pubescens (Benth.) Benth. (Leguminosae, \\ Papilionoideae)
}

Superar la latencia en semillas de Pterodon pubescens (Benth.) Benth. (Leguminosae, Papilionoideae)

Rithiely Conceição Silva

ORCID: https://orcid.org/0000-0002-8302-6702 Universidade do Estado de Mato Grosso, Brasil

E-mail: rithielycs@gmail.com

Solange Kimie Ikeda Castrillon

ORCID: https://orcid.org/0000-0003-1862-4615 Universidade do Estado de Mato Grosso, Brasil

E-mail: ikedac@gmail.com

José Ricardo Castrillon Fernandez

ORCID: https://orcid.org/0000-0002-3011-1997 Instituto Federal de Educação, Ciência e Tecnologia de Mato Grosso, Brasil

E-mail: jrcastrillon@gmail.com

Fernando Ferreira de Morais

ORCID: https://orcid.org/0000-0001-7111-2833

Universidade Federal da Paraíba, Brasil

E-mail: fernandobotanica@gmail.com

Alessandra Aparecida E. Tavares Morini ORCID: https://orcid.org/0000-0003-1158-3718 Universidade do Estado de Mato Grosso, Brasil E-mail: ikedac@gmail.com

Josué Ribeiro da Silva Nunes ORCID: https://orcid.org/0000-0003-3927-5063 Universidade do Estado de Mato Grosso, Brasil E-mail: josue@unemat.br

\begin{abstract}
Pterodon pubescens is a native species, popularly known as "faveiro", "sucupira-branca", "fava-de-sucupira", "sucupira", and "sucupira-lisa", belonging to the family Leguminosae-Papilionoideae (Fabaceae). This study aimed to analyze the effect of different treatments on the breaking of seed dormancy in Pterodon pubescens (Leguminosae, Papilionoideae). The seeds were collected in four places in the municipality of Cáceres (Mato Grosso, Brazil). They were selected by flotation or deposition in a container with water, washed with sodium hypochlorite $(2 \%$ active chlorine), and subjected to five treatments, as follow: (T1) control, (T2) seeds had their woody integument removed and were washed with detergent; (T3) seeds were scarified and immersed in a container containing $500 \mathrm{ml}$ of cola-based soft drink, for an hour and a half; (T4) seeds had only their integument removed; and (T5) seeds were subjected to scarification, using a file, until the embryo was visible. T2 and T4 were the most effective treatments for the emergence of $P$. pubescens seed.
\end{abstract}

Keywords: Emergence; Dormancy; Treatments.

\section{Resumo}

Pterodon pubescens é uma espécie nativa, popularmente conhecida como faveiro, sucupira-branca, fava-de-sucupira, sucupira, sucupira-lisa, pertence à família Leguminosae-Papilionoideae (Fabaceae). O presente trabalho teve por objetivo analisar o efeito de tratamentos para quebra de dormência das sementes de Pterodon pubescens (Leguminosae, Papilionoideae). A coleta das sementes foi realizada em quatro pontos, no município de Cáceres, Mato Grosso. Foram selecionadas por flutuação ou deposição em recipiente contendo água, lavadas com hipoclorito de sódio a $2 \%$ de cloro ativo e submetidas a cinco tratamentos. $\mathrm{O}$ primeiro tratamento foi testemunho. $\mathrm{O}$ segundo foi a retirada do tegumento lenhoso das sementes e lavagem com detergente. No terceiro houve escarificação das sementes, seguida de imersão em recipiente contendo $500 \mathrm{ml}$ de refrigerante a base de cola, por uma hora e meia. No quarto, as sementes tiveram somente 
a retirada do tegumento. O quinto, as sementes foram submetidas à escarificação com lima até verificar o embrião. Os tratamentos mais eficazes para trabalhar com emergência da espécie Pterodon pubescens, foram T2 (retirada do tegumento e detergente) e T4 (retirada do tegumento).

Palavras-chave: Emergência; Dormência; Tratamentos.

\section{Resumen}

Pterodon pubescens es una especie nativa, popularmente conocida como faveiro, sucupira-branca, fava-de-sucupira, sucupira, sucupira-lisa, pertenece a la familia Leguminosae-Papilionoideae (Fabaceae). El presente trabajo tuvo como objetivo analizar el efecto de los tratamientos para romper la latencia de las semillas de Pterodon pubescens (Leguminosae, Papilionoideae). La recolección de semillas se realizó en cuatro puntos, en el municipio de Cáceres, Mato Grosso. Se seleccionaron por flotación o deposición en un recipiente con agua, se lavaron con hipoclorito de sodio al $2 \%$ de cloro activo y se sometieron a cinco tratamientos. El primer tratamiento fue el testimonio. El segundo fue la eliminación de la cubierta de la semilla leñosa y el lavado con detergente. En el tercero, se escarificaron las semillas, seguido de inmersión en un recipiente que contenía $500 \mathrm{ml}$ de refresco a base de cola, durante una hora y media. En el cuarto, a las semillas solo se les quitó el tegumento. El quinto, las semillas se sometieron a escarificación con cal hasta verificar el embrión. Los tratamientos más efectivos para trabajar con la emergencia de la especie Pterodon pubescens, fueron T2 (remoción del tegumento y detergente) y T4 (remoción del tegumento).

Palabras Clave: Emergencia; Entumecimiento; Tratos.

\section{Introduction}

Pterodon pubescens (Benth.) Benth. is native to Brazil, popularly known as "faveiro", "sucupira-branca", "fava-desucupira", "sucupira", and "sucupira-lisa", and belongs to the family Leguminosae-Papilionoideae (Fabaceae). This species occurs in the states of Minas Gerais, São Paulo, Goiás, and Mato Grosso do Sul, especially in the Cerrado and in the transition to the semi-deciduous forest in the Paraná basin Lorenzi (2002).

This plant has potential for naval and civil construction, bridges, charcoal, landscaping, including for composing lists of species for the restoration of degraded areas. The crude ethanolic extract of its bark was described by Bustamante (2010) as effective against the microbial activity of sporulated and non-sporulated Gram-positive and Gram-negative bacteria, and the fungus Candida albicans. Its seeds have great medicinal value, especially for traditional populations who use them to treat inflammatory diseases. Some of the compounds in its seed showed efficacy against schistosomiasis Denny (2002).

The seed is an organ of paramount importance for the perpetuation and dissemination of plant species due to two characteristics, which combined, make possible "the ability to distribute germination in time, by dormancy mechanisms, and in space, by dispersion mechanisms such as thorns, hair, wings, etc.” Carvalho \&Nakagawa (2000).

According to Zeiger (2009), seed germination can be defined as the resumption of growth of the mature seed embryo. Light, temperature, water, growth medium, container, nutrients, allelopathy, fauna, and microorganisms are the main environmental factors that influence germination Floriano (2004).

However, some internal (longevity, viability) and external (water, temperature, and oxygen) factors can influence germination. The internal factors are influenced by the relationship between the environmental and genetic characteristics and the external ones are all environmental factors, which have an important role in the seed germination process Carvalho \& Nakagawa (2000). Thus, knowing and controlling environmental factors may allow us to optimize the rate, speed, and uniformity of germination.

P. pubescens seeds have integumentary dormancy, which makes their germination difficult, occurring slowly and in a small percentage. Thus, it is necessary to use methods to overcome seed dormancy to accelerate and increase the germination rate in this species Albuquerque et al. (2007).

Dormancy occurs in some cases, in which, even under favorable conditions, a viable (alive) seed tends to have a delay in the germination process Zeiger (2009). This phenomenon is an evolutionary factor, ensuring greater seed resistance and viability for a long period, contributing to the successful dispersion process. The high heterogeneity of factors necessary for 
germination and the physiological process, called dormancy, require specific knowledge to produce quality seedlings with efficiency and agility Abdo \& Fabri (2015).

Two types of dormancy are considered in the literature, namely: integumentary dormancy and embryo dormancy. The dormancy imposed on the embryo by the seed testa and other surrounding tissues, such as the endosperm, pericarp, or extrafloral organs, is known as testa-imposed dormancy. In this case, seed embryos will germinate quickly in the presence of water and oxygen, as soon as the testa and other surrounding tissues have been removed or damaged. In the case of embryo dormancy, it is intrinsic to the embryo and does not result from any influence of the seed testa or other surrounding tissues. In some cases, the embryo dormancy can be interrupted by the excision of cotyledons Zeiger (2009).

In some species, seed bark or integument thickness varies greatly from seed to seed, thus preventing the exchange of water and gases with the external environment, leading to irregular germination in the same batch of seeds. Therefore, the plants do not develop all at once, but gradually. Several Fabaceae trees have this type of dormancy (imposed by the testa), allowing the seeds to germinate at different points, times, and places, increasing the chances of survival of some specimens and the species establishment as a whole Mori et al. (2012).

The dormant seeds or buds have no response to those apparently favorable conditions because they contain endogenous inhibitors, which must be removed or neutralized before the dormancy period ends Raven et al. (2014).

Seeds have some dormancy mechanisms or systems, functioning in an integrated manner together with the plant structures. These systems refer to the control of water entry into the seed, control of the embryonic axis development, and control of the balance between growth-promoting and inhibiting substances Carvalho \& Nakagawa (2000).

Because of Pterodon pubescens (Benth.) Benth. is important for the restoration of degraded areas and for having tegumentary dormancy, this study aimed to analyze the effect of different treatments on the breaking of seed dormancy in Pterodon pubescens (Benth.) Benth. (Leguminosae, Papilionoideae).

\section{Methodology}

\section{Study area}

Seeds were collected in the municipality of Cáceres (Mato Grosso, Brazil), which covers an area of 24,593,123 $\mathrm{km}^{2}$ and has an estimated population of 93,882 inhabitants (IBGE 2018). The region has a mean annual rainfall of 1,323 mm, a mean temperature of $25^{\circ} \mathrm{C}$ and, according to the classification proposed by Kottek et al. (2006), Aw climate, with dry winter, from May to October, and rainy summer, from November to April. The Paraguay River is the main drainage channel in the municipality and has great importance for the Pantanal Mato-grossense, which is the most representative biome in the region Silva et al. (2008).

The collections were performed at four places The first and second ones on the MT-343 highway $\left(16^{\circ} 04^{\prime} 5.1^{\prime \prime} \mathrm{S}\right.$; $57^{\circ} 36^{\prime} 9.6^{\prime \prime} \mathrm{W}$ and $16^{\circ} 04^{\prime} 21^{\prime \prime} \mathrm{S} ; 57^{\circ} 37^{\prime} 1.2^{\prime \prime} \mathrm{W}$, respectively) and the third and fourth places on a perimeter road (16 $06^{\circ} 12.2^{\prime \prime} \mathrm{S}$; $57^{\circ} 38^{\prime} 30.9^{\prime \prime} \mathrm{W}$ and $16^{\circ} 06^{\prime} 15.9^{\prime \prime} \mathrm{S} ; 57^{\circ} 38^{\prime} 29.8^{\prime \prime} \mathrm{W}$, respectively).

The experiment was conducted in the Environmental Education and Ecological Restoration Laboratory and in a nursery of the State University of Mato Grosso (UNEMAT), Campus Cáceres.

\section{Study Method}

We based on quantitative methods for carrying out the experiments, and according to Pereira et al. (2018) these methods generate sets of data that can be analyzed using mathematical techniques and predict possible relationship to some phenomenon under study. 
The collected seeds were stored in a BOD chamber and subsequently subjected to different pre-planting processes. Seeds were selected by flotation or deposition in a container with water (floated seeds were considered nonviable and deposited seeds were viable for planting) and washed with sodium hypochlorite ( $2 \%$ active chlorine) for disinfection. Afterward, the viable seeds were subjected to five treatments, as follow: (T1) control; (T2) seeds had their woody integument removed, using pruning shears, and subsequently washed with detergent; (T3) seeds were scarified, followed by immersion in a container containing 500 $\mathrm{ml}$ of cola-based soft drink, for an hour and a half; (T4) seeds had only their integument removed; and (T5) seeds were subjected to scarification, using a file, until the embryo was visible.

A completely randomized design was used, with five replications of 25 seeds for each treatment, totaling 625 seeds. The seeds were sown in a bed $(0.5 \mathrm{~cm}$ in depth) containing washed sand as a substrate, irrigated, and monitored daily, from October 13 to December 21, 2017.

The following parameters were assessed: mean emergence time (MET), emergence speed index (ESI), emergence percentage (\% E), according to Ferreira \& Borghetti (2004), and emergence evolution. The results were subjected to analysis of variance (ANOVA) and the Tukey test for comparison of means, using the BioStat software.

\section{Results and Discussion}

During the experimental period (70 days), the results showed a statistically significant difference between treatments. T2 (seed integument removal and washing in detergent) and T4 (seed integument removal) were the most effective treatments, accounting for $24 \%$ and $15.2 \%$ emergence, respectively. T1 (control), T5 (scarification), and T3 (scarification and immersion in cola-based soft drink) had the lowest percentage $(2.4 \%, 1.6 \%$, and $0.8 \%$, respectively) (Fig. 1). Given that the analyzed seeds are covered with a woody layer containing oil glands, it is recommended to isolate the endocarp to intensify the germination rate in this species Matos et al. (2007).

Figure 1. Emergence percentage of Pterodon pubescens (Benth.) Benth. seeds, in the municipality of Cáceres (Mato Grosso, Brazil). T1 - Control, T2 - Integument removal and washing in detergent, T3 - Scarification and immersion in cola-based soft drink, T4 - Integument removal, T5 - Scarification.

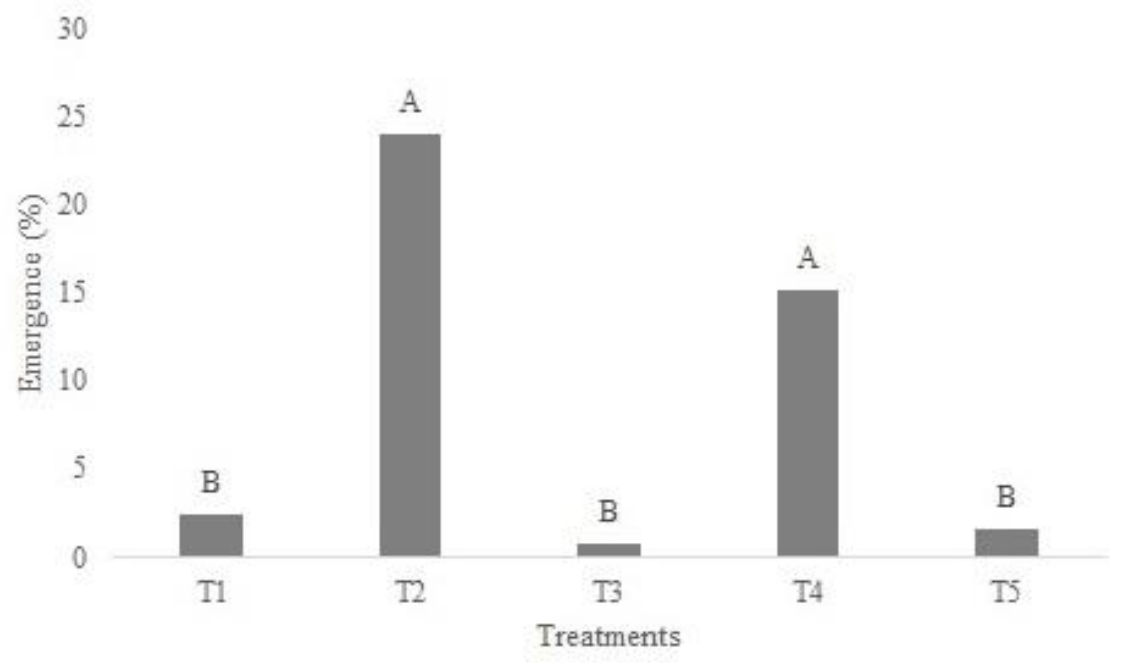

*Means followed by the same letter do not differ significantly by the Tukey test at 5\% probability. Source: Authors. 
There are limitations in obtaining seedlings of Pterodon pubescens because its seeds have integumentary dormancy, making their germination difficult, which occurs slowly and in a small percentage. Thus, when collected, its fruits can be directly planted or have their seed integument removed before planting, which is a more efficient method Tavares et al. (2015).

T2 and T4 had the lowest MET (mean emergence time), lasting $16 \pm 4$ days and $30 \pm 22.4$ days, respectively, differing from T1 (64 \pm 12.7 days), T3 (65 \pm 12.9 days), and T5 (59 \pm 22.47 days) (Fig. 2). According to Ferreira et al. (2001), fruits of $P$. pubescens should not be subjected to germination test, due to a small percentage of normal seeds, being necessary to remove the seed integument. This explains the best results from treatments in which seed integument was removed.

Figure 2. Mean emergence time of Pterodon pubescens (Benth.) Benth. seeds, in the municipality of Cáceres (Mato Grosso, Brazil). T1 - Control, T2 - Integument removal and washing in detergent, T3 - Scarification and immersion in cola-based soft drink, T4 - Integument removal, T5 - Scarification.

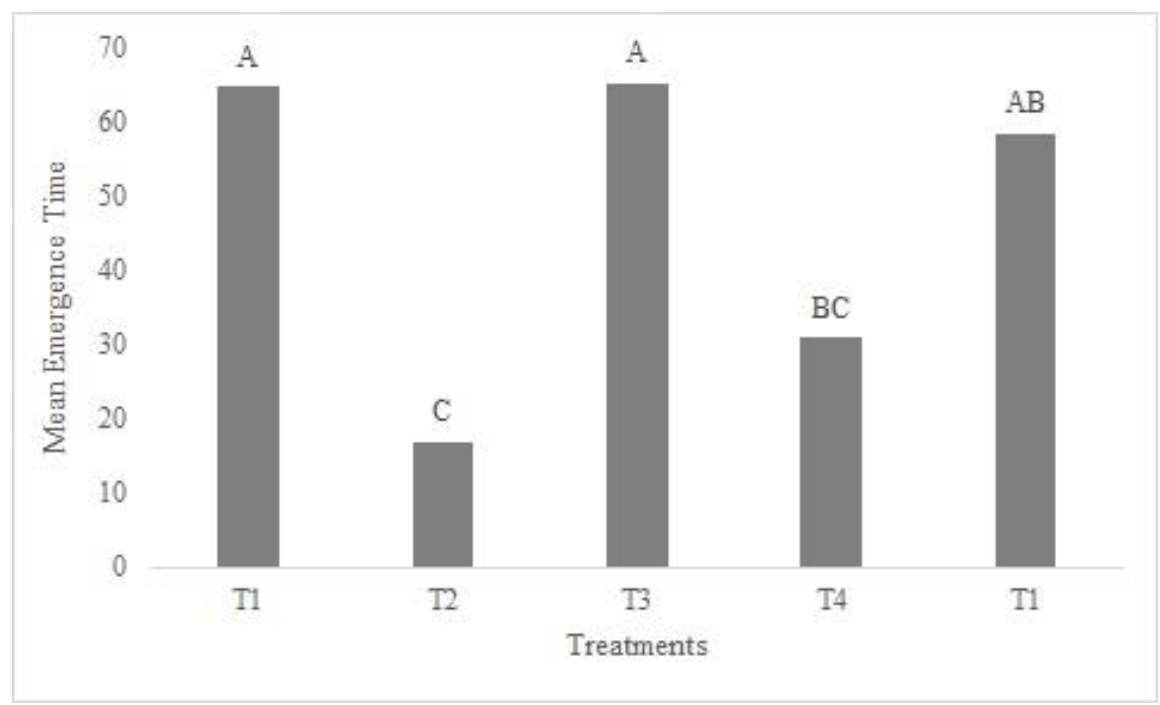

*Means followed by the same letter do not differ significantly by the Tukey test at $5 \%$ probability. Source: Authors.

Regarding the evolution analysis, T2 and T4 had the best results, being the first ones to have their seeds emerged; however, T2 had a higher number of emerged seeds (30), followed by T4 (19 seeds). T1 (control) had 3 emerged seeds and was the last one to emerge, T5 (scarification) had 2 emerged seeds, the third one to emerge, and T3 (scarification and immersion in a cola-based soft drink) had only one emerged seed and was the fourth one to emerge (Fig. 3). 
Figure 3. Germination evolution of Pterodon pubescens (Benth.) Benth. seeds, in the municipality of Cáceres (Mato Grosso, Brazil). T1 - control, T2 - integument removal and washing in detergent, T3 - scarification and immersion in cola-based soft drink, T4 - integument removal, and T5 - scarification.

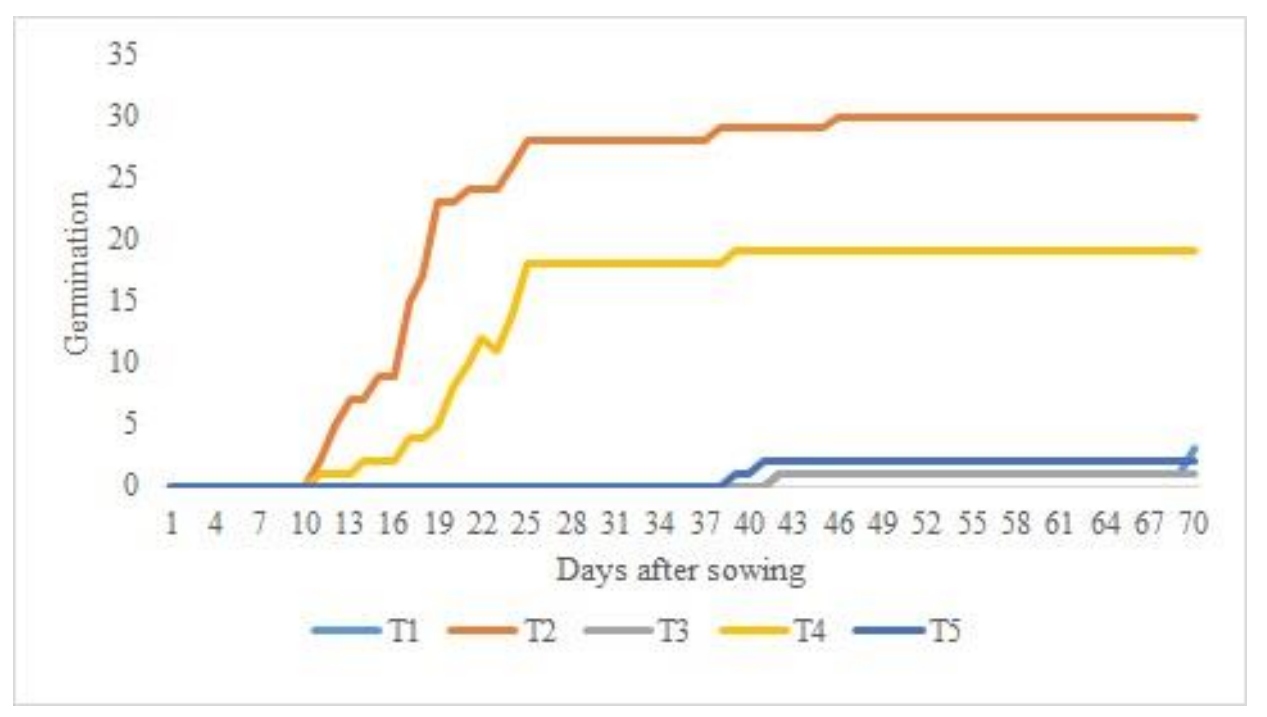

Source: Authors.

Cortelete et al. (2017), studying Pterodon emarginatus Vog. recorded that the removal of seed integument is the best treatment for overcoming seed dormancy in this species. This is because this process promotes the entry of water into the seed and gas exchange, necessary for the embryo to emerge. Coelho et al. (2001), through germination analysis "in vitro", found that seed integument removal resulted in a higher number of germinated seeds in comparison with their integument section. This can be explained by the fact that the sectioned integument continued to hinder the water entry into the seed, whereas seeds that had their integument removed had a larger contact surface.

Concerning the ESI (emergence speed index), T2 and T4 had the most prominent values (5.85 and 4.68 plants per day, respectively) and did not differ statistically from each other but differed from T1, T3, and T5, which had the lowest ESI (0.01, 0.10, and 0.23 plants per day, respectively) (Fig. 04). Matos et al. (2007), studying dormancy overcoming in Pterodon emarginatus Vog., found an adverse effect on ESI and germination rate when subjecting seeds to cutting and immersion in water for 48 hours. However, seeds subjected to sulfuric acid and thermal shock treatments did not differ statistically from the control seeds. 
Figure 4. Emergence speed index (ESI) of Pterodon pubescens (Benth.) Benth. seeds, in the municipality of Cáceres (Mato Grosso, Brazil). T1 - Control, T2 - Integument removal and washing in detergent, T3 - Scarification and immersion in colabased soft drink, T4 - Integument removal, T5 - Scarification.

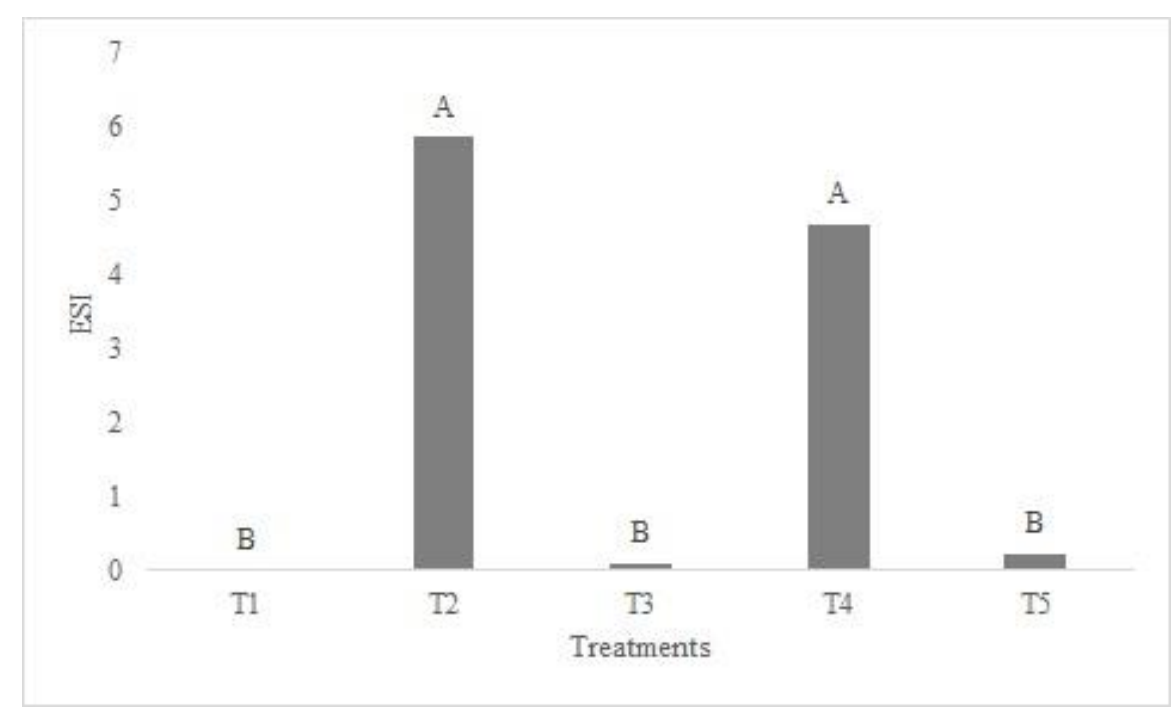

*Means followed by the same letter do not differ significantly by the Tukey test at 5\% probability. Source: Authors.

Corrêa \& Bertuci (2012), after three months analyzing the breaking of integumentary dormancy in seeds of Pterodon emarginatus Vog., observed no germination in none of the treatments, evidencing the difficulty in producing seedlings of species belonging to this genus.

The germinated seeds were transplanted to tubes for later use in the recovery of springs. A total of 55 seedlings were produced.

\section{Conclusion}

T2 and T4 were better than the others, with emergence of $24 \%$ and $15.2 \%$, respectively. T2 (integument removal and washing in detergent) and T4 (integument removal) had the best mean emergence time (16 \pm 4 and $30 \pm 22.4$ days, respectively), as well as the highest ESI (5.85 and 4.68 plants per day, respectively). In the evolution analysis, they also proved to be the best, resulting in a higher number of germinated seeds (30 and 19, respectively), which were the first ones to emerge.

From the results, it is concluded that T2 (integument removal and washing in detergent) and T4 (integument removal) are the most effective treatments for the emergence of Pterodon pubescens (Benth.) Benth. seeds.

The emergence of Pterodon pubescens (Benth.) Benth. is very slow and occurs in a small percentage. Therefore, it was evident the importance of applying pre-germinative treatments to obtain seedlings.

We observed that studies of this nature can instrumentalize the production of seedlings for the restoration of degraded areas, as well as promoting the improvement of local environmental quality. In this way, we suggest that other germination methods be tested and widely disseminated to the different social actors, so that they in their communities can have access to scientific technical information, which can favor the process of producing seedlings of regional native plant species.

\section{References}

Albuquerque, K. S., Guimarães, R. M., Almeida, I. F., \& Clemente, A. C. S. (2007). Métodos para a superação da dormência em sementes de sucupira-preta (Bowdichia virgilioides Kunth.). Ciência Agrotécnica de Lavras, 31(6): 1716-1721. 
Abdo, M. T. V., \& Fabri, E. G. (2015). Transferência de tecnologia: guia prático para quebra de dormência de sementes de espécies florestais nativas. Pesquisa $\&$ Tecnologia, 12(2):1-7.

Bustamante, K. G. L., Lima, A. D. F., Soares, M. L., Fiuza, T. S., Tresvenzol, L. M. F., Bara, M. T. F., Pimenta, F. C., \& Paula, J. R. 2010.Avaliação da atividade microbiana do extrato etanólico bruto da casca da sucupira branca (Pterodon emarginatus Vogel.) - Fabaceae. Revista Brasileira de Plantas Medicinais, Botucatu, 12(3): $341-345$.

Brasil. IBGE. Cidades e estados. (2018). Https://cidades.ibge.gov.br.

Carvalho, N. M., \& Nakagawa J. (2000). Sementes: ciência, tecnologia e produção. (4th ed.), FUNEP. 588 p.

Coelho, M. C. F., Pinto, J. E. B. P., Morais, A. R., Cid, L. P. B., \& Lameira, O. A. (2001). Germinação desementes e propagação in vitro de sucupira branca [Pterodon pubescens (Benth.) Benth.]. Ciência agrotecnica, Lavras, 25 (1): 38-48.

Cortelete, B. P., Duarte, I., Silva, R. C., Silva, P. E. O., Jesus, W. J. T., Silva, S. A., Farias, J. S., Alexandre, R. F., Martins, B. A., Cruz, L. E., \& Fernandez, J. R. C. Germinação de sementes e a prática de viveiros educadores no Assemtamento Laranjeira I. In: Castrillon, S. I., Pul, J. I., Marais, F. F., \& Lopes, A. A. E. T. M. (Org). Escassez hídrica e Restauração Ecológica no Pantanal: Recuperação de nascentes e fragmentos de mata ciliar do córrego no Assentamento Laranjeira I e mobilização para conservação dos recursos hídricos no Pantanal mato-grossense. Cuiabá: Carline \& Caniato Editorial, 2017. p. 195-206.

Correa, T. C. S., Bertuci, J. L. (2012). 018 - Avaliação de quebra de dormência tegumentar em sementes de sucupira-branca (Pterodon emarginatus Vog.) submetidas a diferentes tratamentos. Cadernos de Agroecologia, 7(2). <http://revistas.aba-agroecologia.org.br/index.php/cad/article/view/13047>.

Denny C. 2002. Atividade Antiinflamatória Do Óleo De Sucupira Pterodon pubescens Benth. Leguminosae-Papilionoideae. 101 f. Dissertação (Mestrado em Odontologia) - Universidade Estadual de Campinas, Piracicaba/SP.

Fowler, J. A.P., \& Bianchetti, A. (2000). Dormência em sementes florestais. Embrapa Florestas (documentos, 40), Colombo. 27 p.

Ferreira, R. A., Vieira, M. G. G.C., Von Pinho, E. V. R., \& Tonetti, O. A. O. 2001. Morfologia da semente e de plântulas e avaliação da viabilidade da semente de sucupira-branca (Pterodon pubescens Benth. - Fabaceae) pelo teste de tetrazólio. Revista Brasileira de Sementes, Brasília, 23(1): 108-115.

Ferreira, A. G., \& Borghetti, F. (2004). Germinação: do básico ao aplicado. Artmed. 323 p.

Floriano, E. P. (2004). Germinação e dormência de sementes florestais. Caderno didático nº 2. Santa Rosa. 19 p.

Kottek, M., J. Grieser, C. Beck, B. Rudolf \& F. Rubel, (2006). World map of the Köppen-Geiger climate classification updated. Meteorologische Zeitschrift, 15: $259-263$.

Lorenzi, H. (2002). Árvores brasileiras: manual de identificação e cultivo de plantas arbóreas do Brasil. vol. 1, (4th ed.), Nova Odessa, SP: Instituto Plantarum. 368 p.

Mori, E. S., Rodrigues, F. C. M. P., \& Freitas, N. P. (2012). Sementes florestais: Guia para germinação de 100 espécies nativas. São Paulo: Instituto Refloresta. 159 p.

Matos, P. S., Nascimento, R. S. M., Araújo, G. P., Cerqueira, R. C., \& Reis, A. T. C. C. (2007). Superação de Dormência Tegumentar em Sementes de Pterodon emarginatus Vog. (sucupira-branca) - Leguminosae (Papilionoideae). Revista Brasileira de Biociências, Porto Alegre, 5 (2): $720-722$.

Pereira, A. S., Shitsuka, D. M., Parreira, F. J., \& Shitsuka, R. (2018). Metodologia da pesquisa científica. UAB/NTE/UFSM. https://repositorio.ufsm.br/bitstream/handle/1/15824/Lic_Computacao_Metodologia-PesquisaCientifica.pdf?sequence=1.

Raven, P. H., Evert, R. F., \& Eichhorn, S. E. (2014). Biologia vegetal. Tradução Ana Claudia M. Vieira et al. (8th ed.), Guanabara Koogan. 876 p.

Silva, A., Filho, E. E. S., \& Cunha, S. B. (2008). Padrões de canal do rio Paraguai na região de Cáceres (MT). Revista Brasileira de Geociências, 38(1): 167177.

Taiz, L., \& Zeiger, E. (2008). Fisiologia Vegetal. (4th ed.) Artmed. 820 p.

Tavares, D. V. L., Matins, N. P., Barros, W. S., \& Souza, L. C. D. (2015). Metodologia de quebra de dormência em sementes de sucupira-branca. Rev. Conexão Eletrônica, Três Lagoas, MS, 12(1): 1-9 